to prosecute individuals who make false claims in order to access government funds.

Mann is the co-author of the famous 'hockey stick' graph, which shows estimated global temperatures over the last millennium to have been relatively constant until a drastic rise in the twentieth century. Mann has long been a target of climate-change deniers, and the scrutiny intensified last autumn when his e-mails were among those stolen from the Climatic Research Unit at the University of East Anglia, UK. But Mann's research has been upheld by the US National Academy of Sciences, and an investigation by Pennsylvania State University into the e-mails also cleared Mann of any misconduct. Given the lack of any evidence of wrongdoing, it's hard to see Cuccinelli's subpoena - and similar threats of legal action against climate scientists in a February report by climate-change denier Senator James Inhofe (Republican, Oklahoma) - as anything more than an idealogically motivated inquisition that harasses and intimidates climate scientists.

Certainly Cuccinelli has lost no time in burnishing his credentials with far-right 'Tea Party' activists, many of whom hail him as a hero. In March, he instructed Virginia's state university presidents that they had no legal authority to protect homosexuals under their non-discrimination policies. He has also filed lawsuits challenging health-care reform and the Environmental Protection Agency's authority to issue greenhouse-gas regulations.

Cuccinelli's actions against Mann hark back to an era when tobacco companies smeared researchers as part of a sophisticated public relations strategy to raise doubts over the science showing that tobacco caused cancer, and delayed the introduction of smoking curbs for decades. Researchers found themselves bogged down in responding to subpoenas and legal challenges, which deterred others from the field. Climate-change deniers have adopted similar strategies with alacrity and, unfortunately, considerable success.

Cuccinelli has insisted that he is not "targeting scientific conclusions". But even several climate sceptics who count themselves among Mann's fiercest critics have publicly condemned the attorney general's move. Thankfully, so have many academic bodies. One of them was the University of Virginia's faculty senate, which on 5 May declared that Cuccinelli's "action and the potential threat of legal prosecution of scientific endeavor that has satisfied peer-review standards send a chilling message to scientists engaged in basic research involving Earth's climate and indeed to scholars in any discipline."

Well said. Scientific organizations must respond quickly and forcefully any time political machinations threaten to undercut academic freedom. And, rather than complying, the University of Virginia should explore every avenue to challenge the subpoena.

\section{Advising the adviser}

\section{Europe's Joint Research Centre needs to find its place alongside the new chief scientific adviser.}

very night, under cover of darkness, boats set out into the E Mediterranean Sea to fish illegally. But they can no longer do so invisibly, thanks to a detection system designed and operated by an institute of the European Commission's Brussels-based Joint Research Centre (JRC). The system collects location data signalled to coastal stations from transponders on approved fishing vessels, and combines them in real time with satellite images at a resolution as low as 8 metres that can identify the boats without transponder signals - among which are the illegal fishing ships.

This is just one of several examples of how the JRC's seven institutes develop and apply technologies to support European Union (EU) policies. In the institute devoted to health and consumer protection, for instance, researchers validate methods to replace, reduce or refine the use of animals in safety testing of chemicals; develop tests to detect unauthorized genetically modified organisms in EU markets; and devise the kind of nanoscale measurement methods that will be needed to support future nanoparticle-safety studies.

In some of its research areas, the JRC leads the world - which is all the more striking because the centre, with a budget close to $€ 400$ million (US\$507 million) and a staff of 2,750, was once deemed to be a sluggish and inflexible body. But in the past 12 or so years it has transformed itself into a sharper and more effective organization that last year won unaccustomed approval from an evaluation panel led by the former UK science adviser David King.

Since then, the JRC has been working to implement King's report recommendation that it should go further still, and have a more proactive role in advising the European Commission, Parliament and Council instead of just responding to their immediate needs. Last week the JRC unveiled its new — and still evolving - decadal strategy for achieving that goal.

But because this comes at a time when commission president José Barroso is planning to create a new, high-level post of chief scientific adviser within his cabinet, a question arises. How should the new adviser and the JRC interact?

It is still early days - the role of the chief scientific adviser has not been defined. But it is clear that the adviser's office will have a small staff, and will thus be dependent on information gathering from elsewhere. The JRC would like to be its major pillar of support, and its 10 -year plan includes two activities that could help to achieve this. One is the provision of 'policy options', which would allow policymakers to base their decisions on dispassionate technical analyses of the pros and cons of each course of action. The other is identifying new issues and technologies - synthetic biology, for example - that might require a policy response in the future.

As valuable as those initiatives might be, however, and as admirable as the JRC's self-reform has been, the chief scientific adviser should not be constrained to listening to any single organization, least of all one that is part of the commission. He or she should be free to seek independent input from anywhere in the world.

The JRC's prime mission must be to remain a world-class technical resource for the EU, helping to protect its people against everything from natural and man-made catastrophes to illegal fishing. If it develops its strategy in the same positive spirit that has animated its reinvention over the past dozen years, the long-awaited chief scientific adviser will no doubt be glad to give its technical input serious weight — without treating it like an absolute mandate. 